\author{
Kartavykh 5., \\ Komandyrov 0., \\ Kulikov P., \\ Ploskyi V., \\ Poltorachenko N., \\ Terenchuk $\mathbf{S}$.
}

\section{ADAPTATION OF FUZZY INFERENCE SYSTEM TO SOLVE ASSESSMENT PROBLEMS OF TECHNICAL CONDITION OF CONSTRUCTION OBJECTS}

Основним завданням, на вирішення якого орієнтована робота, є автоматизачія системи нечіткого виведення, яка являє собою одну з підсистем системи оцінки технічного стану об'єктів будівництва. Запропонована система оцінки призначається для служб, які спеціалізуються на проведенні будівельно-технічних експертиз. Прочес проведення експертиз у иій галузі супроводжується невизначеністю різного характеру, а продукиійна діяльність фахівиів часто грунтується на евристиках. Саме тому, об'єктом дослідження $\epsilon$ моделі та засоби, що здатні функціонувати в нечітких умовах. Для автоматизацї експертної діяльності в сфері оцінки впливу зовнішніх факторів на технічний стан об'єктів ущільненої міської забудови спроєктовано спещіалізовану систему оцінки, засновану на знаннях і штучній нейро-нечіткій мережі категорії Takagi-Sugeno-Kang. Застосування нейро-нечітких моделей для нечіткого виведення надає змогу автоматизувати процес одержання логічних висновків із вхідних даних за заданими експертами нечіткими правилами. При иьому налаштування функиій приналежності може здійснюватись за допомогою штучних нейронних мереж. Нечітка нейронна мережа Takagi-Sugeno-Kang nризначається для вирішення цієї задачі. Доцільність використання цієї моделі до вирішення задачі оцінки технічного стану об'єктів будівнищтва з пошкодженнями обгрунтована ї̈ здатністю до розв'язання задачі нечіткої класифікаиї. Другим основним критерієм вибору цієі моделі стала можливість задавати правила функцією входів, оскільки в умовах ущільненої міської забудови фактори впливу зовнішнього середовища на технічний стан об'єктів носять складний нелінійних характер. Принщип адаптацї системи нечіткого виведення показано на прикладі фазифікацї впливів зовнішнього середовища, що спричиняються вібраціями різного характеру. Проведені в роботі дослідження, на відміну від попередніх, розширюють базу знань системи за рахунок представлення інформацї про реальний стан середовища, в якому функціонують об'єкти будівництва. Очікуєтьсл, що застосування штучної нейронної мережі Такаги-Сугено-Канга надасть можливість суттєво знизити вплив людського фактору на виконання будівельно-технічних експертиз, які здійснюються в умовах композиційної невизначеності. Практична значимість роботи полягає в скороченні термінів проведення та підвищенні надійності оцінки технічного стану об'єктів будівництва з пошкодженнями різного характеру.

Ключові слова: система нечіткого виведення, спещіалізована інтелектуальна система, ущільнена міська забудова, итучна нейронна мережа.

\section{Introduction}

Modern construction practice in the conditions of compacted urban building has revealed an increase in the number of tasks associated with changing the complex of loads and impacts on construction objects (objects). Timely implementation of effective measures to adapt these facilities to external conditions, which were not taken into account in the design and construction, requires an assessment of their technical condition. Recommendations for the further operation of such facilities provide for predicting the nature of development and the degree of danger of identified defects.

Such forecasting is justified by a system of rules that are determined in each case. Specialists know which system of rules should be used in a particular case to take into account possible environmental impacts and are able to give recommendations on the further operation of facilities even in conditions of uncertainty. However, such recommendations are based on special knowledge and heuristics.

The use of insufficiently formalized specialized knowledge in computerized complexes requires the development and implementation of expert applications that can reproduce the production thinking of experts. This means that adaptation of the fuzzy inference system to the solution of the problem of assessing the technical condition of construction objects remains an urgent and timely task [1, 2]. But, one of the significant drawbacks of fuzzy inference systems is that they are not able to automatically obtain the knowledge used in inference mechanisms. Overcoming the above problems is seen in the development of a system for assessing the technical condition of objects with a neuro-fuzzy inference system, in which the inference is 
performed by fuzzy logic methods, and membership functions are configured using an artificial neural network [3]. That is why, the object of research are models and tools capable of solving the problem of fuzzy classification. And the aim of research is the conceptual modeling of a specialized intellectual system with a neuro-fuzzy inference system and its adaptation to the solution of the problem of assessing the technical condition of construction objects in a densely populated urban area.

\section{Methods of research}

The methodology for adapting the fuzzy inference system to the task of assessing the technical condition of construction objects is based on the application of fuzzy rules in a fuzzy logical basis. This makes it possible to formalize the process of assessing the technical condition of objects and build a system of fuzzy models that reproduce fuzzy logical reasoning of experts. Subsequently, these models form the ontology of the system [3].

Fig. 1 shows a model of a fuzzy inference system, which is a control system based on fuzzy logic [4].

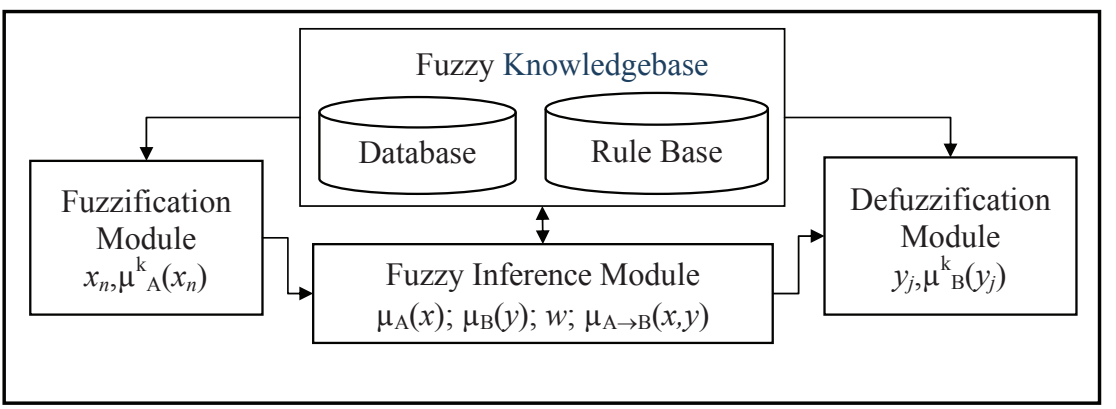

Fig. 1. Model of a Fuzzy Inference System

The structure of the system and the principle of setting parameters and rules using universal software systems are described in $[4,5]$.

The possibility of applying fuzzy inference systems to solving various applied problems was shown in [6], but the use of such systems requires the adaptation of a fuzzy knowledge base to solve such domain problems as [7, 8]:

- interpretation of knowledge;

- fuzzification and defuzzification of data;

- formalization of rules for the formation of possible conclusions.

For fuzzification and defuzzification of data in the system database, membership functions for all input and output variables $\left(\mu_{A}=\left\{\mu_{A}\left(x_{1}\right) ; \ldots ; \mu_{A}\left(x_{n}\right) ; \ldots ; \mu_{A}\left(x_{N}\right)\right\}\right.$ and $\mu_{B}=$ $\left.=\left\{\mu_{B}\left(x_{1}\right) ; \ldots ; \mu_{B}\left(x_{k}\right) ; \ldots ; \mu_{\mathrm{B}}\left(x_{K}\right)\right\}\right)$ and the weights of the rules $(w)$, which are used to obtain conclusions $(A \rightarrow B)$.

To formalize fuzzy rules, according to which conclusions are drawn and their membership measures are determined $\left(\mu_{A \rightarrow B}(x, y)\right)$, fuzzy inference systems use fuzzy implications or production models [4].

The principle of forming the base of rules reproduces the fuzzy logical reasoning of experts in solving problems of ensuring the reliability and operational suitability of an object at the operation stage is shown in [5, 7]. However, in these works, the main attention is paid to the issues of fuzzification of the geometric parameters of damage to structural elements of objects and fuzzy derivation of logical conclusions on this input. In addition, the assessment of the technical condition of the object as a whole requires the use of a different system of rules, determined by the reduction degree of the bearing capacity of structures, taking into account the influence of various environmental factors in each individual case.

In [8], the process of fuzzy inference is formalized for the task of assessing the degree of influence of construction work on the deterioration of the technical condition of objects that were nearby. But the task of assessing the influence of anthropogenic and natural factors on the technical condition of the facilities is not limited to repair and construction work.

In [9], questions of the influence of the external environment on the rate of degradation of building materials are investigated and an information technology for the diagnosis of reinforced concrete structures using an integrated automation system for design work is proposed. The proposed system is able to function in real time, but its development and implementation requires filling the knowledge base with real data.

A systematic analysis of the information contained in the reports on the results of the examination of the technical condition of existing facilities allows using the expert method to establish the membership measures of the input data and fill the database of the fuzzy output system with real data. The conclusions of experts on the possible reasons for the deterioration of the technical condition of various objects operated under various conditions are systematized, generalized and formalized in the form of fuzzy models that form the basis of the rules for evaluating analogous objects.

Fig. 2 shows the placement of one of the objects of research on the example of the building of the Khanenko National Museum of Art (Kyiv, Ukraine).

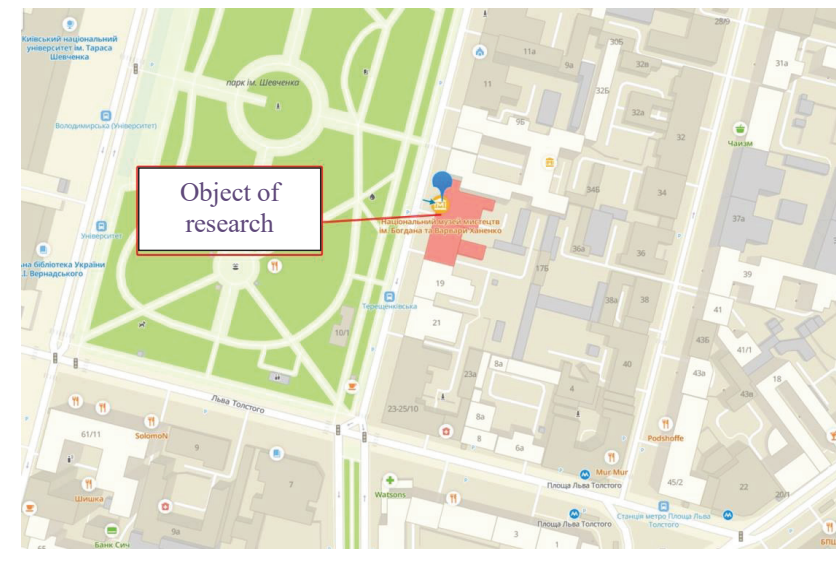

Fig. 2. Placing the object of research on a fragment of a Kyiv map (Ukraine)

The technical condition of the building (Ukraine, Kyiv, Tereschenkivska St., 15-17) is investigated in connection with the reconstruction.

A fragment of the results of processing input variables is shown in Table 1. 
Fragment of fuzzification of environmental influences on the technical condition of an object

\begin{tabular}{|c|c|c|c|}
\hline No. & Source of vibration & $\begin{array}{l}\text { Influence characteristics } \\
\qquad\left(X=\left\{x_{1} ; \ldots ; x_{I}\right\}\right)\end{array}$ & $\begin{array}{l}\text { Measure of the } n \text {-th } \\
\text { influence on } k \text { damage } \\
\qquad\left(\mu^{k}{ }_{A}\left(w_{n}\right)\right)\end{array}$ \\
\hline 1 & $\begin{array}{l}\text { traffic on Tereschen- } \\
\text { kivska street }\end{array}$ & \multirow{6}{*}{$\begin{array}{l}\text { amplitude }\left(x_{2}\right) \\
\text { distance to source }\left(x_{3}\right) \\
\text { distribution conditions }\left(x_{4}\right)\end{array}$} & not significant $(n=1)$ \\
\hline \multirow{2}{*}{2} & \multirow{2}{*}{ subway functioning } & & moderate $(n=2)$ \\
\hline & & & medium ( $n=3)$ \\
\hline \multirow{3}{*}{3} & \multirow{3}{*}{$\begin{array}{l}\text { repair and construc- } \\
\text { tion work carried out } \\
\text { in connection with the } \\
\text { reconstruction }\end{array}$} & & significant $(n=4)$ \\
\hline & & & critical $(n=5)$ \\
\hline & & & exceeds critical $(n=6)$ \\
\hline
\end{tabular}

Since this work focuses on the problems of assessing the technical condition of objects operating in a densified urban development environment, first of all, the general properties and characteristic features of significant environmental factors on the technical condition of the object are investigated.

Such factors, first of all, include vibrations of a different nature.

Vibration sources can be various natural phenomena, transport networks, construction activities, and other technogenic phenomena.

These impact factors can lead to the development of negative processes, the assessment of the degree of influence of which on the technical condition of objects is complicated by the fact that [7]:

- there is no clear boundary between measures

of influence on an object of vibrations of various origin;

- increases the likelihood of a situation where individual environmental factors have little effect on the original sign, and their combined effect is significant and are complex non-linear.

Thus, taking into account the characteristic features of external factors influencing the technical condition of urban development objects shows the feasibility of choosing such an artificial neural network for integration into the assessment system, which:

- is developed to solve the problem of fuzzy classification;

- capable of handling functions that are complex nonlinear.

Earlier in [7], based on an analysis of the ability of artificial neural networks of various architectures to solve various problems, it was proposed to use the Takagi-SugenoKang artificial fuzzy neural network to assess the technical condition of building structures with damage. This model calculates the output using the Takagi-Sugeno-Kang input function [10].

In addition, the Takagi-Sugeno-Kang artificial neural network integrates with the Sugeno fuzzy logical inference system [2, 10], which is more rational for constructing inference rules for diagnosing the technical condition of objects if, as a result of examinations, the input data is given by clear values.

Such a choice of the model makes it possible [7, 10]:

- set rules reflecting the influence of the environment on the technical condition of the object, by the function of inputs;
- take into account the nonlinear nature of the dynamics of the development of damage through the use of a nonlinear input layer.

In [7] also:

- network architecture is defined;

- rule is provided according to which the number of neurons of the input and output layers is determined;

- structure of connections and the appointment of neurons of each layer is described;

- choice of network training method is substantiated.

Thus, in [7] it is shown that the trained TakagiSugeno-Kang fuzzy neural network is advisable to use in intelligent systems for assessing the technical condition of damaged objects that are operated in a densely populated urban area.

\section{Research results and discussion}

The model of the structure of the system of assessment of technical condition of construction objects with an integrated artificial neural network Takagi-Sugeno-Kang is shown in Fig. 3.

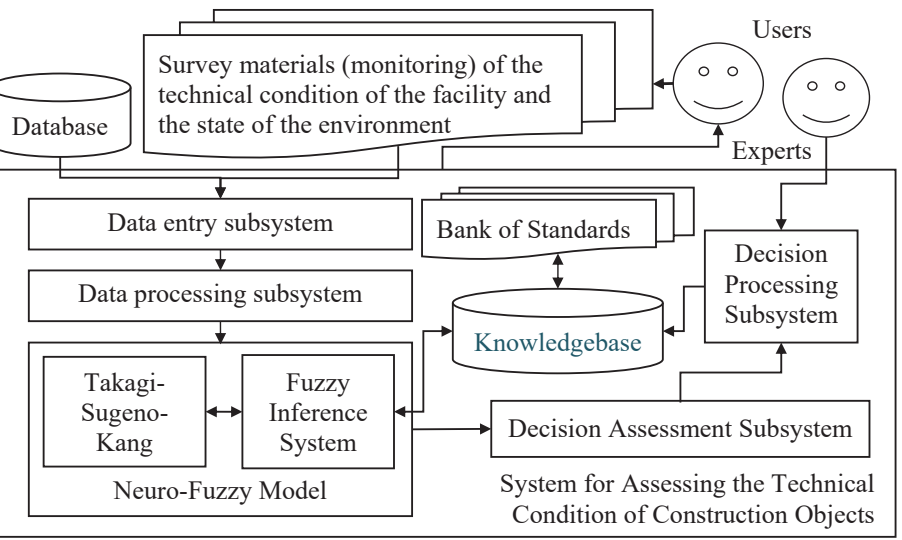

Fig. 3. The scheme of integration of the artificial neural network Takagi-Sugeno-Kang in the system for assessing the technical condition of construction objects

The users of the assessment system are experts who evaluate the technical condition of the construction object.

Experts in Fig. 3 are specialists who ensure reliable operation of the system, namely:

- fill the knowledge base of the system with special

knowledge at the development stage;

- control the adequacy of setting membership functions at the training stage;

- regulate conflict issues (if any) at the operation stage.

Input data enter the assessment system through the input subsystem of input data from the database and from services that provide surveys of the technical condition of objects. It is assumed that the external database contains the necessary information to fill the knowledge base of the system for assessing the technical condition of construction objects in accordance with the problem being solved.

The bank of standards contains templates that adequately reflect the technical state of objects and data streams that can be used to predict the dynamics of the behavior of input parameters using an artificial neural network. 
The input processing subsystem is assigned the procedures for generating the vector of input variables, which are fed to the fuzzification module of the fuzzy inference system (Fig. 1).

It should be noted that the justification of the development of intelligent systems for assessing the technical condition of objects of individual construction objects remains in question. However, there are a large number of standard objects that have been reduced at the same time and have been operated for a long time in the same external conditions. If to take into account the number of objects that require examination of the technical condition, then doubts about the justification of the development and implementation of new methods and means of ensuring the reliability and safety of their operation disappear.

Moreover, the rapid development of hybrid technologies makes it possible to use fuzzy systems to display generalized expert knowledge on the architecture of artificial neural networks with their subsequent training on real data [11, 12]. Thus, the use of neuro-fuzzy inference models makes it possible to automate the process of obtaining logical conclusions from input according to fuzzy rules specified by experts.

\section{Conclusions}

The specialized intellectual system for assessing the technical condition of construction objects with a neuro-fuzzy inference system proposed in the work is assigned to services that specialize in conducting construction and technical examinations. Expert activity in this area is accompanied by uncertainties of a different nature, and the production activities of experts are often based on heuristics. Adaptation of the fuzzy inference system by using binding heuristics will significantly reduce the sample size for training an artificial neural network, and speed up the learning process of the system.

The use of the Takagi-Sugeno-Kang artificial neurofuzzy network in the designed assessment system implies the availability of clear data that are necessary to generate the Takagi-Sugeno-Kang function. Therefore, further work is planned to be directed to the study of objects functioning in the areas of a significant and critical effect of vibrations on their technical condition.

\section{Acknowledgement}

The work is based on the analysis of scientific and technical reports and expert assessments of the technical condition of the buildings of the Khanenko National Museum of Art. Assessments were carried out under the supervision of the head of the Department of Foundations and Foundations of the Kyiv National University of Construction and Architecture, Doctor of Technical Sciences, Professor I. Boiko on the order of the private enterprise «ABC - Architectural and Construction Center» (Kyiv, Ukraine). The authors are grateful to the management of the enterprise for information support of research aimed at introducing new, scientifically based technologies and systems into the processes of conservation and ensuring reliable and safe operation of architectural heritage objects.

\section{References}

1. Driankov, D., Hellendorm, H., Reich Frank, M. (1996). An Introduction to Fuzzy Control. Berlin: Springer. doi: http://doi.org/ 10.1007/978-3-662-03284-8
2. Tanaka, K., Wang, H. O. (Eds.) (2001). Fuzzy Control Systems Design and Analysis: a Linear Matrix Inequality Approach. New York: Wiley, 320.

3. Subbotin, S. A. (2006). Sintez raspoznaiuschikh neiro-nechetkikh modelei s uchetom informativnosti priznakov. Neirokompiutery: razrabotka, primenenie, 10, 50-56.

4. Osowski, S. (2000). Siecin euronowe do przetwarzania informacji. Warszawa, 342.

5. Terenchuk, S., Yeremenko, B., Sorotuyk, T. (2016). Implementation of intelligent information technology for the assessment of technical condition of building structures in the process of diagnosis. Eastern-European Journal of Enterprise Technologies, 5 (3 (83)), 30-39. doi: http://doi.org/10.15587/17294061.2016.80782

6. Shastri, A., Stitt, G., Riccio, E. (2015). A scheduling and binding heuristic for high-level synthesis of fault-tolerant FPGA applications. 2015 IEEE 26th International Conference on Application-Specific Systems, Architectures and Processors (ASAP). doi: http://doi.org/10.1109/asap.2015.7245735

7. Terenchuk, S., Pashko, A., Yeremenko, B., Kartavykh, S., Ershova, N. (2018). Modeling an intelligent system for the estimation of technical state of construction structures. Eastern-European Journal of Enterprise Technologies, 3 (2 (93)), 47-53. doi: http:// doi.org/10.15587/1729-4061.2018.132587

8. Pasko, R., Terenchuk, S. (2020). The Use of Neuro-Fuzzy Models in Expert Support Systems for Forensic Building Technical Expertise. ScienceRise, 2, 10-18. doi: http://doi.org/ 10.21303/2313-8416.2020.001278

9. Yeremenko, B. M. (2015). Design of intelligent system for diagnostics of technical state of building objects. Technology Audit and Production Reserves, 1 (2 (21)), 44-48. doi: http:// doi.org/10.15587/2312-8372.2015.37506

10. Tanaka, K., Yoshida, H., Ohtake, H., Wang, H. O. (2009). A Sumof-Squares Approach to Modeling and Control of Nonlinear Dynamical Systems With Polynomial Fuzzy Systems. IEEE Transactions on Fuzzy Systems, 17 (4), 911-922. doi: http:// doi.org/10.1109/tfuzz.2008.924341

11. Mendel, J. M. (2017). Uncertain Rule-Based Fuzzy Systems: Introduction and New Directions. Springer. doi: http://doi.org/ 10.1007/978-3-319-51370-6

12. Wu, D., Lin, C.-T., Huang, J., Zeng, Z. (2019). On the Functional Equivalence of TSK Fuzzy Systems to Neural Networks, Mixture of Experts, CART, and Stacking Ensemble Regression. IEEE Transactions on Fuzzy Systems, 1. doi: http://doi.org/ 10.1109/tfuzz.2019.2941697

Kartavykh Serhii, Chief Project Engineer, ABC-architectural and construction center, Kyiv, Ukraine, e-mail: snk07@ukr.net, ORCID: http:// orcid.org/0000-0003-2287-4297

Komandyrov Oleksii, Head of Department of Research of Project Documentation and the Cost of Construction Work, Kyiv Scientific Research Institute of Forensic Expertise of the Ministry of Justice of Ukraine, Ukraine, e-mail: budassist@gmail.com, ORCID: http:// orcid.org/0000-0002-3655-780X

Kulikov Petro, Doctor of Economics, Professor, Rector, Kyiv National University of Construction and Architecture, Ukraine, e-mail: terenchuksa@ukr.net, ORCID: http://orcid.org/0000-00027379-7968

Ploskyi Vitalii, Doctor of Technical Sciences, Professor, Department of Architectural Constructions, Kyiv National University of Construction and Architecture, Ukraine, e-mail: terenchuksa@ukr.net, ORCID: http://orcid.org/0000-0002-2632-8085

Poltorachenko Natalia, PhD, Associate Professor, Department of Information Technology Design and Applied Mathematics, Kyiv National University of Construction and Architecture, Ukraine, e-mail: poltorachenko@gmail.com, ORCID: http://orcid.org/00000002-2238-6130

Terenchuk Svitlana, PhD, Associate Professor, Department of Information Technology Design and Applied Mathematics, Kyiv National University of Construction and Architecture, Ukraine, e-mail: terenchuksa@ukr.net, ORCID: http://orcid.org/0000-00027141-6033 